\title{
Foreign Citizens in Finland as Recipients of Social Security Benefits
}

\author{
HELKA HYTTI, D.Soc.Sc., Senior Researcher ${ }^{1}$ \\ SEPPO PAANANEN, D.Soc.Sc, Senior Researcher ${ }^{2}$ \\ ${ }^{1}$ The Social Insurance Institution, Helsinki, Finland \\ ${ }^{1}$ Docent in Demography, Helsinki University, Finland \\ ${ }^{2}$ Statistics Finland, Helsinki
}

\begin{abstract}
This article looks at recipiency rates for social security benefits and active labor market measures among working-age foreign residents of Finland, and compares them to the corresponding rates among Finnish citizens. Data for the study was obtained by collating individual-level data from the Finnish population register, various social security registers, the student financial aid register and the jobseeker register maintained by the employment authorities. The analysis focuses on unemployment benefits, maternity and parental allowances, child home-care allowances, income support and financial aid benefits for students. The study reflects the situation as of November 2000.
\end{abstract}

The results show substantial variation among the ethnic groups in terms of social security recipiency. The highest recipiency rates were seen among refugees, followed by persons having entered Finland on a passport issued in Russia or the former Soviet Union. As for participation in active labor market measures, Russians and citizens of the former Soviet Union, refugees and Estonians had significantly higher recipiency rates than the general Finnish population. Another finding suggesting a high level of motivation towards labor market participation in the abovementioned groups is that young persons in these groups were nearly as likely as young Finnish citizens to receive financial assistance for studies, either in the form of financial aid benefits or labor market training.

Keywords: Immigrants, integration, foreign citizen, social security, labor market 


\section{Introduction}

The central objective of this study is to provide information about the use of social security benefits among immigrants to Finland. A second objective is to compare benefit recipiency among immigrants and the general population. The analysis is limited to immigrants who were not Finnish citizens at the end of 2000. We focus particularly on various forms of provision during unemployment, benefits in respect to maternity and the home-care of children, and minimum income support. In the context of unemployment provision, we look at both "passive benefits" and participation in active labor market (ALM) measures. Though not properly classifiable as social expenditure, financial aid for students will also receive some attention from us, given that it is possible to see it as a counterbalance to social security benefits in the sense that education can eventually end welfare dependency.

Within the last ten years, Finland's migration balance has turned positive. An increase in immigration was first seen around 1990, at a time when the Finnish society was still relatively unprepared for it. After a first wave of immigration consisting of Ingrian return migrants and Somali refugees, the ethnic diversity of the immigrants has gradually increased. The reception given to immigrants was complicated by the fact that the increase in immigration coincided with the worst economic recession in Finnish history. A large share of immigrants have suffered from persistent unemployment, and hence the rate of unemployment among immigrants is still substantially higher than among the population in general. Unemployment also colors the general attitude towards immigrants: negative attitudes towards foreigners, while less prevalent than in 1993 (during the economic recession), were still common in 1999 (Jaakkola 1999).

At the end of 2001, there were in Finland a little over 145,000 persons of foreign origin, 98,600 of whom were foreign citizens. The share of foreign citizens in the Finnish population (1.9 percent) is lower than in any other E.U. Member State. The largest group of foreigners consists of Russians and persons having entered Finland on a passport of the former Soviet Union (including most of the Ingrian return migrants), nearly 25,000 of whom were resident in Finland at year-end 2001. Estonian citizens numbered approximately 11,700 and Somali citizens 4,400 . The increasing integration of immigrants into Finnish society is reflected in more and more immigrants having become naturalized citizens. Among Somali immigrants, for instance, about 2,300 had obtained Finnish citizenship. (Statistics Finland 2002.)

Unemployment and welfare dependency among return migrants and immigrants became the central theme of the public debate on foreigners during the 1990s, although it has so far not featured as a topic in political discussions (Paananen 2002). A substantive discussion is precluded also by the scarcity of research data on well-being and use of social security benefits among immigrants. 
There has recently been a debate in Finland about whether to take active steps to promote labor immigration. This debate was sparked by the fact that the Finnish workforce will begin to diminish within the next few years as the large post-war cohorts approach retirement age (Pinomaa 2001; Vesterinen 2002). Another issue involved in the debate is the enlargement of the European Union, which inspires both dreams and fears, not least because there have been conflicting assessments about how it would affect the volume of immigration and labor mobility. There are concerns that the enlargement will create new problems for social security and labor policy, owing to the gap in living standards between old and new Member States and differences in their domestic labor markets (Laukkanen 2001; Sosiaalimenojen kehitys pitkällä aikavälillä 2002, 77-79; VNK 2001).

Unemployment, welfare dependency and negative attitudes towards foreigners are some of the key themes in research on the well-being of immigrants. What makes things more complicated for this research is that these issues are tightly interwoven and tend to feed into each other. For example, it is reasonable to assume that immigrant unemployment generates negative attitudes towards immigration and perhaps even racism. A large share of the immigrants who entered Finland in the 1990s are or have recurrently been dependent on social security. According to the first Finnish study on welfare recipiency among immigrants (Forsander 2002, 199), 61 percent of immigrants received some taxable social security benefit during 1997. Income transfers were most common among the ethnic groups with the largest family units and the lowest employment rate, which accounts for the fact that unemployment benefit was the single most common benefit received, with 47 percent of immigrants having been on unemployment benefit sometime during 1997.

Similar results were obtained from the other Nordic countries. For example, a Danish study found that income transfers to immigrants from developing countries grew from 1991 to 1995 and 1996. On the other hand, immigrants from developed countries (the E.U. countries, Norway, Iceland, Switzerland, North America, Australia and New Zealand) were net contributors to social security. (Wadensjö 1999.) In Norway, nearly 90 percent of recent immigrants ( $1-2$ years of residence) received income support in 1997. Even after seven years of residence, more than 50 percent of refugees in Norway remained on income support. (Djuve et al. 2001, 12). The cause of the higher utilization of social security benefits among immigrants was their low employment rate (lower than that of the general population).

Also in the general population, utilization of social security benefits increased as a result of the recession and mass unemployment. In Finland as in the other Nordic countries, the general consensus is that the best way to combat welfare dependency is employment integration and the improvement of employability, for example, by means of vocational training. Upgrading skills is seen as beneficial equally for the general population and for the immigrants (Finland's National Action Plan....2001, 12). 
Particular importance is attached to the employment integration of immigrants, as it is considered to promote social integration and to alleviate anti-immigrant sentiment in the general population. For these reasons, the promotion of employment is the main method of integration policy.

\section{Integration policy and residence-based social security in Finland}

A theoretical concept used in the public debate on immigrant well-being is integration, which often refers to the desirable outcomes of the peaceful coexistence of ethnic groups. In both the public debate and the discourse within the research community, integration often represents the positive counterpart of assimilation, which carries a negative value. (Sander 1997.) The Finnish word kotoutuminen was coined in the late 1990s as the Finnish equivalent of "integration". Kotoutuminen carries positive connotations of "domestic comfort" and "feeling at home". Straddling the middle ground between assimilation and segregation, it aims to avoid the negative aspects associated with those two words

In the Nordic Welfare State model, the social integration of ethnic groups is perceived as an important part of labor market, social welfare and education policies. This thinking is rooted both in the strong role of the state in taking responsibility for people's wellbeing and in the ideal of social equality, and is further motivated by the consensus expectation that people must accept the existing norms and abide by common rules. The integration policies also have relevance to the continued legitimacy of the Nordic social model insofar as they entail that the rights of immigrants be founded on the same principles as those of the general population, so as not to endanger the principle of universalism so central to the Nordic model. While activation and training measures are the main instruments of integration in labor market policy, they must be supported and complemented by social security schemes giving immigrants the same rights as the general population. (Forsander 2002, 73-84).

The key legislative instrument governing the relationship between immigrants and the Finnish society is the Act on the Integration of Immigrants and the Reception of Asylum Seekers. Drafted in the Ministry of Labor, the Act became effective in 1999. It applies to all immigrants - whatever their country of origin - who have been in Finland for three years or less and who claim income support (the benefit of last resort provided by municipal authorities) or the state-provided labor market subsidy payable to new labor market entrants.

The key component in the integration process is the individual integration plan, which each immigrant prepares in cooperation with the social welfare and employment au- 
thorities. It outlines "measures to support the immigrant and the immigrant's family in acquiring the necessary knowledge and skills needed in society and working life" (VNS 5/2002, 17-18). The measures can include language instruction in Finnish or Swedish, preparatory training, on-the-job training, labor market training, career counseling, and supporting the integration of the children and adolescents in the family. The local government authorities and the employment office have a responsibility to draw up an individual integration plan and the immigrants have the right and responsibility to participate in both the drafting and the implementation of the plan. Should an immigrant refuse to do so, the amount of integration assistance can be reduced (VNS 5/2002, 21). Eligibility labor market subsidy is conditional on the drafting of and compliance with the plan. Income support, on the other hand, must be provided by the local authorities even where no integration plan exists.

The number of individuals covered by the integration assistance scheme at the end of 2001 was rather small, only about 16,000 persons, 5,700 of whom were referred by the employment office and 10,000 by the local government authorities (VNS 5/2002, 19).

In Finland as in the other Nordic countries, eligibility for social security is determined on the basis of residence or employment. Citizenship is usually irrelevant in terms of the enjoyment of social rights. In principle, therefore, immigrants with a residence permit valid for at least a year have the same rights to social security as the general population. For this study, we have selected social security benefits which are based on residence and have been suspected of attracting immigration. They include universal unemployment benefits, family benefits linked to childbirth and childrearing, and income support. A study grant is not considered a social security benefit, but rather an investment into the future. Sickness benefits and pensions have been left entirely out of the discussion. Pensions are rarely paid to immigrants, as they require a previous residence of three to five years. In the following, we shall outline the benefits discussed.

Unemployment Relief, with focus on the Labor Market Subsidy. Among the various benefits payable in regard to unemployment, our main attention will be on the labor market subsidy, which is an important form of unemployment relief for unemployed immigrants. This benefit is paid both to unemployed persons who are just entering the labor market and to those who do not satisfy the statutory requirement concerning the length of previous employment (at least 10 months within the last two years). Further, the labor market subsidy is available to those who have reached the 500-day cap on unemployment relief. The labor market subsidy is a means-tested benefit: both the unemployed person's own income and the income of his/her spouse decrease the amount of labor market subsidy and, given a high enough level of income, can prevent payment altogether. The labor market subsidy is also payable during participation in labor market training measures, in practical training or in rehabilitation measures associated with work. The data also gives us information about the earnings-related unemployment 
allowances paid by unemployment funds and the basic allowances payable to persons who have not joined an unemployment fund but fulfil the requirement concerning previous employment. However, these two benefits have only a very marginal relevance to immigrants.

Maternity and Parenthood Allowance, payable for a total of 263 working days in connection with the birth of a child. During the first 105 days, the allowance is always paid to the child's mother; subsequently, it can be paid to either parent. Fathers are also entitled to a paternity allowance. The amount of the allowance is linked to earnings, but everyone is entitled to a defined minimum level of aid. For the purposes of this study, we shall limit our attention to the benefits paid to mothers.

Child Home Care Allowance is a cash benefit whose purpose is to help families with at least one child under three years of age with their child-care arrangements. It provides an alternative to day-care services arranged by the local authorities (all children under school age in Finland have a subjective right to municipal day care). The parents need not care for their child at home themselves, but the great majority of the payments are made to mothers who opt to care for their child at home even after their entitlement to parenthood allowance has ended.

Income Support. The benefit of last resort payable to individuals or households whose income and social security benefits are not sufficient to provide a minimum income as defined in the Act on Social Assistance. Income support is fully mean-tested: all of the household's disposable income and assets are taken into account when determining the need for aid. It is paid by the municipality, whereas other social security benefits are paid from national systems.

Study Grant. Payable for full-time studies after lower secondary school. The amount of the study grant depends on the student's age, whether he/she lives independently or with his/her parents, family circumstances, type of educational institution, and the applicant's personal financial situation. Student benefits are provided to Finnish citizens as well as to employees from E.U. and E.E.A. Member States and their family members. They are also payable to citizens of other countries, provided they have been resident in Finland for at least two years. A shorter time limit is required of refugees.

\section{Research problem and data}

The purpose of this study is to analyze recipiency of residence-based social security benefits and of labor policy measures among foreign citizens living in Finland, and to investigate how the different ethnic groups differ among each other and in relation to the general population in terms of benefit recipiency. The analysis focuses on unem- 
ployment security (covering both "passive benefits" and participation in ALM measures), maternity and parental allowances, child home-care allowances, minimum income support and financial aid benefits for students.

In this study, immigrants are considered to include foreign nationals resident in Finland who have been issued a residence permit valid for at least one year, thus being covered under Finland's social security system. They may have entered Finland as a refugee, migrant worker or spouse, or in the course of a family reunification process. Those immigrants who have been given Finnish citizenship after moving to Finland or who were Finnish citizens upon moving to Finland are excluded from the analysis.

The immigrants have been divided into four groups according to nationality: (1) Westerners (all current E.U. Member States, Iceland, Norway, Switzerland, North America, Australia and New Zealand), (2) Estonians, (3) citizens of Russia and the former Soviet Union and (4) refugees. The last category includes the immigrants from Afghanistan, Bosnia-Herzegovina, Iraq, Iran, Yugoslavia and Former Yugoslavia, Macedonia, Myanmar, Somalia and Vietnam.

The reference point for the analysis is November 2000. All analyses deal with the working-age population between ages 16 and 64 .

This study is part of a larger project whose aim is to provide baseline data about recipiency rates for universal social security benefits and income support provided as a last resort in various population groups, and to study the role of unemployment in creating demand for minimum income support. Data for the study was collected largely with the needs of the larger project in mind. From the specific point of view of this study, the biggest problem in the original study data can be seen in the fact that it does not allow us to distinguish between naturalized and native citizens of Finland, and therefore, our data only covers those immigrants who are not citizens of Finland. Another problem is that Ingrian-Finnish return migrants (currently around 20,000 in number) cannot be distinguished from Russian or Estonian immigrants. Finally, a third problem, concerning both immigrants and the general population, is that the data does not indicate social status (e.g., education, occupation).

The data has been obtained by conflating individual-level data files from the Social Insurance Institution (SII), the National Research and Development Center for Welfare and Health (Stakes), and the Ministry of Labor. The resulting individual-level data set covers the entire working-age population of Finland at the end of 2000. The data comprises five main categories. Three have been obtained from the SII's registers (demographic data, recipiency of universal social security benefits and data on the provision of financial aid to students), two from the register of the Ministry of Labor (data on unemployment and active labor policy measures) and one from Stakes 
(recipiency of minimum income support). All subject-identifying information has been deleted from the study data.

Table 1 shows the distribution of the working-age population according to the nationality classification used in this study. At year-end 2000, the total working-age population in Finland was 3.4 million out of which 69,800 were foreign citizens living in Finland. About 17,000 of the foreigners were Westerners, 7,700 Estonians, 17,000 from Russia or the former Soviet Union, 10,200 from refugee-origin countries and 17,800 from other countries.

Table 1. The study population: persons of working age resident in Finland at yearend 2000 according to nationality, age and sex.

\begin{tabular}{crrrrrr}
\hline & Fin & West & Est & Rus & Ref & Other \\
\hline Number & & & & & & \\
$16-64$ & $3,384,060$ & 17,030 & 7,710 & 17,020 & 10,200 & 17,830 \\
$16-24$ & 583,190 & 2,200 & 1,500 & 3,100 & 2,820 & 2,290 \\
$25-49$ & $1,767,220$ & 11,420 & 4,960 & 11,010 & 6,640 & 13,220 \\
$50-64$ & $1,033,640$ & 3,410 & 1,240 & 2,910 & 750 & 2,320
\end{tabular}

Age distribution, \%

$\begin{array}{rrrrrrr}16-64 & 100 & 100 & 100 & 100 & 100 & 100 \\ 16-24 & 17.2 & 12.9 & 19.5 & 18.2 & 27.6 & 12.8 \\ 25-49 & 52.2 & 67.1 & 64.4 & 64.7 & 65 & 74.2 \\ 50-64 & 30.5 & 20.0 & 16.1 & 17.1 & 7.4 & 13.0\end{array}$

Female share, $\%$

\begin{tabular}{rrrrrrr}
$16-64$ & 49.5 & 35 & 62.1 & 63 & 46.5 & 45.8 \\
$16-24$ & 48.9 & 44.1 & 54.5 & 52.7 & 50.3 & 51.2 \\
$25-49$ & 49.1 & 34.4 & 63.4 & 66.3 & 44.8 & 44.9 \\
$50-64$ & 50.6 & 31.2 & 66.3 & 61.3 & 47.6 & 45.6 \\
\hline
\end{tabular}

Immigrants are on the whole younger than Finnish citizens. The largest age difference is seen in relation to refugees, 28 percent of whom are between ages 16 and 24 and only 7 percent over the age of 50 , compared to 17 and 31 percent, respectively, among Finnish citizens.

The share of women in the working-age population is roughly the same for refugees as for Finnish citizens ( 47 and 50 percent, respectively). Among Westerners, the share of female immigrants is 35 percent, compared to, on average, 63 percent among immigrants from Estonia or from Russia/the former Soviet Union. 


\section{Benefit recipiency and labor market orientation}

We have applied a two-pronged approach to the analysis of the data: first, we examine the recipiency rates for benefits in different population groups, and second, we compare these population groups on the basis of variables describing their labor market orientation. The analysis of recipiency rates aims to determine, on the basis of social security data, what share of each group receives unemployment or family benefits or income support. Based on register data from the labor administration and student financial aid programs, the second analysis examines labor market orientation by operationalizing it as the proportion of individuals who are studying, undergoing ALM measures or unemployed. The latter two categories will be collectively referred to in the following as jobseekers, denoting persons without paid work who are actively seeking employment on the open labor market.

\section{Recipients of social security benefits}

Welfare dependency varied greatly between the ethnic groups (Table 2 on next page). Among working-age Westerners, 13 percent were on unemployment/family benefit or income support, while the corresponding share among refugees was 62 percent. The second largest recipiency rate (46\%) was seen among citizens of Russia and the former Soviet Union. Among Estonians, the rate was over 28 percent and thus about twice that of Westerners.

The benefit recipiency rates of Westerners and Finns are roughly the same, around 13 percent. However, the comparison is flawed in the sense that at the time of the study about 11 percent of working-age Finns were on full-time pension (Statistical Yearbook of pensioners in Finland 2001), whereas in the other groups pension recipiency is either extremely rare (Westerners) or effectively impossible (refugees). Furthermore, it must be noted that comparisons between different nationalities are complicated by their different age structures (see below).

The differences in the recipiency rates for labor market subsidy and income support were analogous. Of working-age Westerners, a little over five percent were on labor market subsidy, while the corresponding share among Estonians was 16 percent. Among Russians and refugees, one-third received labor market subsidy. Thus, recipiency rates for labor market subsidy and income support were, among refugees, 7-8 times as high, and among Russians and citizens of the former Soviet Union, 5-6 times as high as among Westerners.

Another finding was that all ethnic groups included recipients of integration assistance for immigrants. Among Russians and refugees, roughly one-third received labor market subsidy as integration assistance, compared to about one-fifth among West- 
erners and Estonians. These figures show that the objectives of the Act on Integration Assistance are being met at least to the extent that immigrants of all nationalities have access to integration assistance, thus satisfying the spirit of the Act.

Table 2. Recipients of unemployment benefits, family benefits or income support as a share of the working-age population according to nationality and sex as of November 2000.

\begin{tabular}{|c|c|c|c|c|c|c|}
\hline & Fin & West & Est & Rus & Ref & Other \\
\hline \multicolumn{7}{|l|}{ Both sexes } \\
\hline All benefits & 13.2 & 13.2 & 28.2 & 46.0 & 62.3 & 28.5 \\
\hline Unemployment benefits. total & 8.4 & 7.7 & 18.6 & 35.5 & 37.3 & 17.4 \\
\hline Unemployment allowances & 3.7 & 2.3 & 3.1 & 2.3 & 1.3 & 1.7 \\
\hline Labor market subsidies & 4.6 & 5.4 & 15.5 & 33.3 & 36.0 & 15.7 \\
\hline -integration assistance for immigrants & 0.0 & 1.2 & 3.7 & 13.4 & 10.5 & 5.2 \\
\hline Family benefits. total & 3.1 & 3.2 & 6.2 & 5.9 & 12.4 & 6.8 \\
\hline Parental allowance & 1.4 & 1.4 & 2.2 & 1.9 & 4.9 & 2.6 \\
\hline Child home-care allowance & 1.7 & 1.9 & 4.0 & 3.9 & 7.6 & 4.3 \\
\hline Income support only & 1.8 & 2.2 & 3.5 & 4.6 & 12.5 & 4.2 \\
\hline Recipients of income support. total & 3.8 & 4.4 & 10.3 & 20.8 & 38.2 & 11.6 \\
\hline \multicolumn{7}{|l|}{ Male } \\
\hline All benefits & 10.2 & 10.2 & 17.5 & 35.6 & 56.2 & 22.6 \\
\hline Unemployment benefits. total & 8.1 & 7.7 & 13.8 & 30.1 & 42.3 & 17.2 \\
\hline Unemployment allowances & 3.2 & 2.3 & 2.5 & 2.2 & 1.7 & 2.0 \\
\hline Labor market subsidies & 5.0 & 5.4 & 11.3 & 27.9 & 40.6 & 15.2 \\
\hline -integration assistance for immigrants & 0.0 & 1.2 & 2.5 & 12.4 & 11.1 & 4.7 \\
\hline Family benefits. total & 0.1 & 0.4 & 0.1 & 0.2 & 0.3 & 0.4 \\
\hline Income support only & 2.0 & 2.2 & 3.6 & 5.4 & 13.6 & 5.0 \\
\hline Recipients of income support. total & 4.1 & 4.4 & 8.4 & 20.5 & 37.3 & 12.4 \\
\hline \multicolumn{7}{|l|}{ Female } \\
\hline All benefits & 16.3 & 18.6 & 34.8 & 52.0 & 69.2 & 35.4 \\
\hline Unemployment benefits. total & 8.6 & 7.9 & 21.5 & 38.7 & 31.5 & 17.7 \\
\hline Unemployment allowances & 4.3 & 2.3 & 3.5 & 2.3 & 0.7 & 1.4 \\
\hline Labor market subsidies & 4.3 & 5.5 & 18.0 & 36.4 & 30.7 & 16.3 \\
\hline $\begin{array}{l}\text {-integration assistance for } \\
\text { immigrants }\end{array}$ & 0.0 & 1.1 & 4.5 & 14.0 & 9.8 & 5.8 \\
\hline Family benefits. total & 6.1 & 8.6 & 9.9 & 9.2 & 26.4 & 14.5 \\
\hline Parental allowance & 2.8 & 3.9 & 3.5 & 3.1 & 10.5 & 5.6 \\
\hline Child home-care allowance & 3.3 & 4.7 & 6.4 & 6.1 & 15.9 & 8.9 \\
\hline Income support only & 1.6 & 2.2 & 3.4 & 4.1 & 11.3 & 3.3 \\
\hline Recipients of income support. total & 3.5 & 4.5 & 11.5 & 21.0 & 39.3 & 10.8 \\
\hline
\end{tabular}


In Finland income support is paid both to top up other benefits and as a benefit of last resort (when an individual or household has no other source of basic subsistence). Due to the cutbacks made in social provision during the 1990s recession and an increase in long-term unemployment, most of the need for income support is now caused by the inadequacy of the primary benefits, particularly in the event of prolonged need for aid.

At the time of the study, about four percent of all working-age Finnish citizens and Westerners were on income support. Among Estonians, the share of income support recipients was 10 percent, among Russians, 21 percent, and among refugees, 38 percent. In all groups, most of the income support payments were made to supplement existing unemployment or family benefits. For example, 38 percent of refugees were on income support, out of which 13 percentage points consisted of those on income support only and 25 percentage points of those receiving unemployment/family benefits at the same time. (Table 2.)

Compared to Finnish women, women in all other ethnic groups were more likely to receive family benefits (Table 2). As expected, female refugees diverged the most from the other groups, with 11 percent receiving maternity or parental allowance and 16 percent child home-care allowance. Among women of other nationalities, the share of maternity and parental allowance recipients varied between three and four percent, and the share of child home-care allowance recipients between three and six percent.

The high recipiency rates for family benefits among female refugees decreased unemployment benefit recipiency at the household level. This can be deduced from the finding that male refugees were considerably more likely to receive labor market subsidy than other ethnic groups, whereas female refugees were second in labor market subsidy recipiency, behind female immigrants from Russia and the former Soviet Union.

Figure 1 (on next page) illustrates the effects of age and gender. Among women of childbearing age, welfare dependency was significantly higher than among men, regardless of nationality. This difference is explained by the benefits provided regarding children. Still, the family benefits received by women do not seem to substitute, at the household level, for unemployment benefits in any other groups besides refugees, or at least not to any significant extent.

With the exception of refugees, women under the age of 25 were as likely or somewhat more likely to receive labor market subsidy than men of the same age. This was also the case with Finnish citizens, even though this particular age group is one in which conscription decreases men's likelihood of being unemployed. 
Figure 1. Share of recipients of social security benefits by sex, age group and nationality, $\%$.

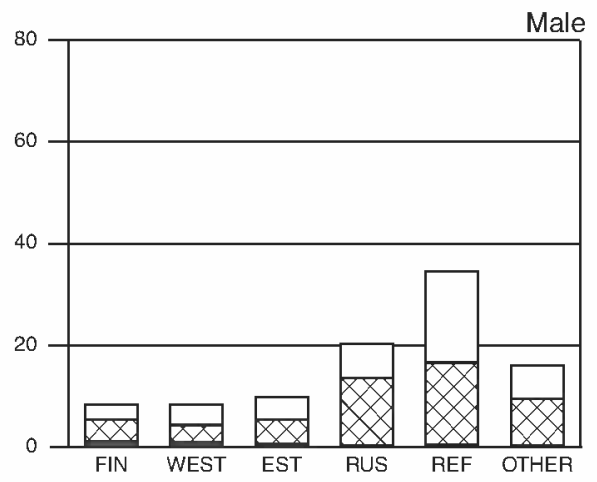

Age 16-24
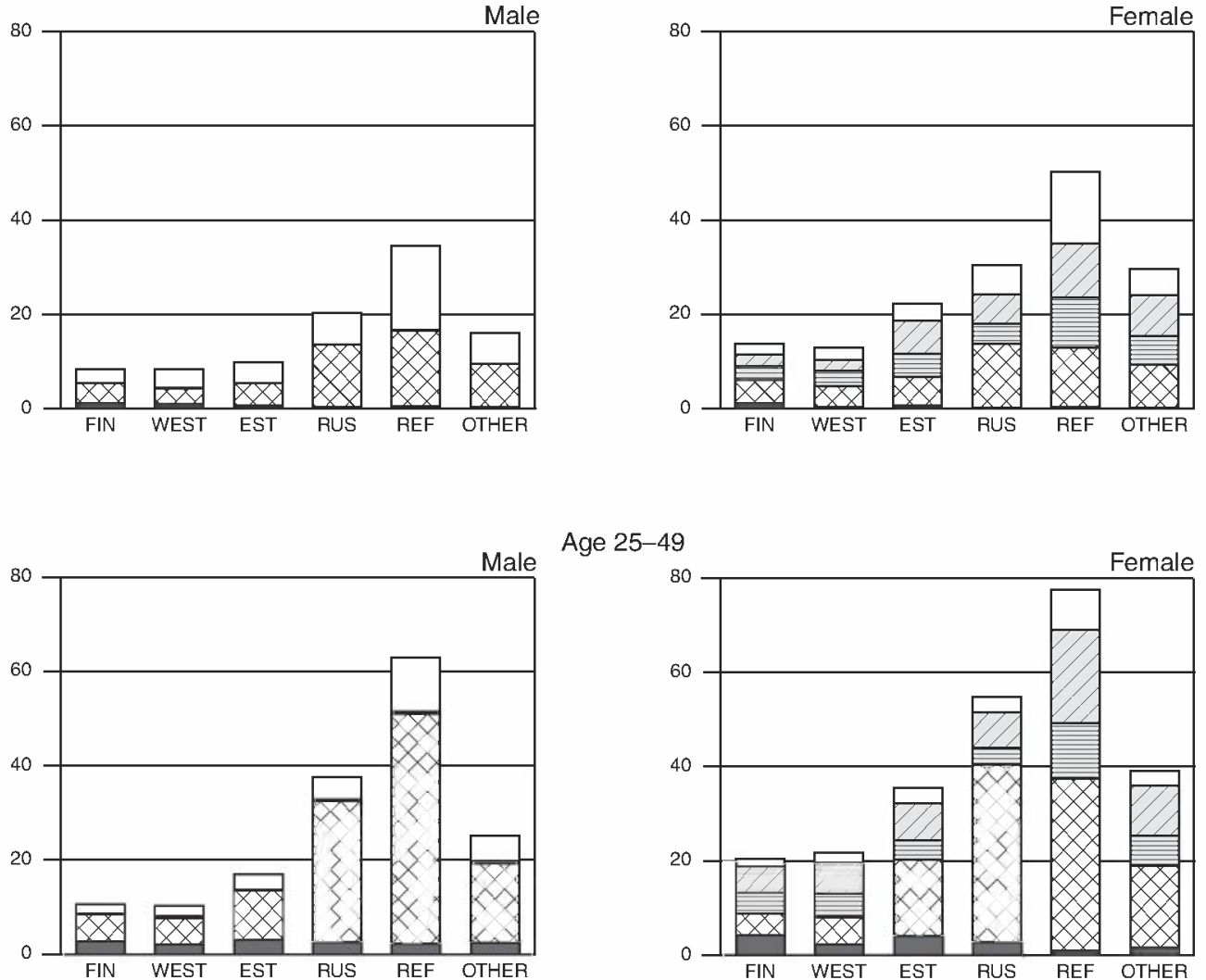

Age 25-49

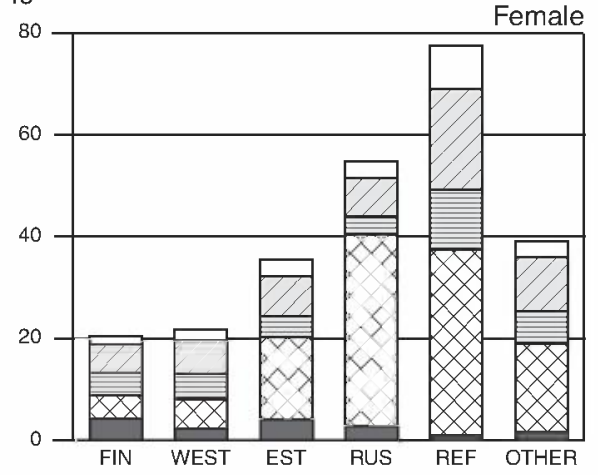

Age 50-64
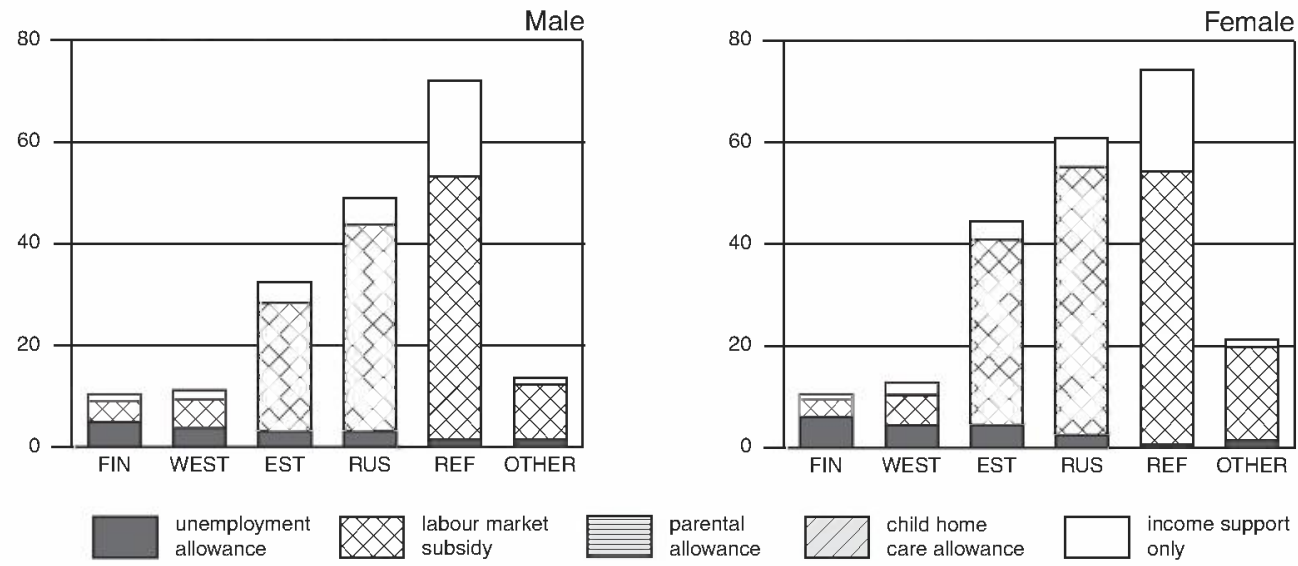
Also in the population aged 25-49 years, women were as likely or more likely to receive unemployment benefits than men of the same age and ethnic background, the only exception, as earlier, being refugees. Among Westerners, unemployment benefit recipiency was roughly as common as among Finns (eight to nine percent), and in both these groups women were slightly more likely to be on the benefit than men. Estonian and Russian women were significantly more likely to receive unemployment benefits than men, by a margin of 20 to 14 percent (among Estonians) and 40 to 33 percent (among Russians). Among refugees, 38 percent of women received unemployment benefit, while the corresponding share among male refugees was 51 percent.

The recipiency rates for family benefits among female immigrants aged 25-49 years were not appreciably different from those for Finnish women of the same age. Again, however, refugees were an exception, with 32 percent receiving either maternity/parental allowance or child home care allowance. Of Finnish women, 10 percent received family benefits, compared to a share of 11-12 percent among Westerners, Estonians and Russians.

In the age group 50-64, women in all ethnic groups were at least as likely to receive unemployment benefits as men. Among Finnish men and women in this age group, nine percent received either unemployment allowance or labor market subsidy. Among Westerners, this share was roughly the same as among the general population, though women were somewhat more likely to receive unemployment benefits than men. Among aging women originally from Estonia or from Russia/the former Soviet Union, a substantially larger share received unemployment benefits than among men with similar backgrounds. The largest rates of unemployment benefit recipiency were seen among refugees, with 54 percent of women and 53 percent of men receiving some unemployment-related benefit.

\subsection{Unemployment and labor market orientation}

One distinctive feature of the Nordic welfare states is that nearly all persons of working age are either in paid employment or receive social security benefits. Eligibility for benefits is conditional on meeting various legislatively mandated criteria for not being able to engage in gainful employment, such as preparation for working life, becoming unemployed through no fault of one's own, raising new generations to resupply the workforce, or incapacity for work. In the case of immigrants, dependence on social security is typically a result of unemployment. The principle of universal social provision dictates that everyone - irrespective of their personal employment history - should have the right to certain basic benefits in respect of unemployment. At the same time, though, eligibility for these benefits is strictly conditional on each recipient's making a genuine effort to earn a living on the open labor market. In this context, the solution to the social integration and subsistence problems encountered by immigrants is seen primarily in the area of training and education and in ALM 
measures preparing them for entry into the labor market. Even more than the general population, immigrants need such support and assistance on account of their weaker labor market status (Forsander 2002, 77).

Table 3 analyzes the labor market orientation of immigrants in relation to all persons of working age in each ethnic group. In terms of labor market orientation, we distinguish between the unemployed and those undergoing ALM measures, including labor market training and supported employment. The population shares of the unemployed and those participating in active measures presented here differ from the indicators generally used in labor force statistics. Here, we analyze the ratio of persons who are unemployed or participating in ALM measures to the whole age group rather than to the workforce (comprising the gainfully employed and the unemployed).

Table 3. Unemployed persons and participants in ALM measures as a percentage of the total working-age population, and participants in ALM measures as a percentage of jobseekers as of November 2000: Analysis by nationality and sex.

\begin{tabular}{|c|c|c|c|c|c|c|}
\hline Both sexes & Fin & West & Est & Rus & Ref & Other \\
\hline \multicolumn{7}{|l|}{$\%$ of working-age population } \\
\hline Jobseekers. total & 10.4 & 10.2 & 21.9 & 39.2 & 42.8 & 20.6 \\
\hline Unemployed & 8.0 & 7.5 & 15.0 & 23.4 & 28.0 & 13.6 \\
\hline Supported employment & 1.2 & 1.0 & 2.3 & 3.1 & 2.3 & 1.4 \\
\hline Labor market training & 1.1 & 1.6 & 4.6 & 12.7 & 12.5 & 5.5 \\
\hline ALM participants. \% of total jobseekers & 22.6 & 26.1 & 31.5 & 40.3 & 34.5 & 33.9 \\
\hline \multicolumn{7}{|l|}{ Male } \\
\hline \multicolumn{7}{|l|}{$\%$ of working-age population } \\
\hline Jobseekers. total & 9.9 & 10.0 & 16.3 & 32.3 & 48.1 & 20.0 \\
\hline Unemployed & 8.1 & 7.6 & 11.6 & 19.6 & 32.6 & 14.0 \\
\hline Supported employment & 0.8 & 0.9 & 1.6 & 2.1 & 2.7 & 1.4 \\
\hline Labor market training & 1.0 & 1.5 & 3.1 & 10.5 & 12.7 & 4.6 \\
\hline ALM participants. \% of total jobseekers & 18.5 & 23.9 & 29.0 & 39.2 & 32.1 & 29.9 \\
\hline \multicolumn{7}{|l|}{ Female } \\
\hline \multicolumn{7}{|l|}{$\%$ of working-age population } \\
\hline Jobseekers. total & 10.9 & 10.5 & 25.3 & 43.3 & 36.7 & 21.3 \\
\hline Unemployed & 8.0 & 7.4 & 17.1 & 25.7 & 22.7 & 13.1 \\
\hline Supported employment & 1.6 & 1.3 & 2.7 & 3.7 & 1.9 & 1.5 \\
\hline Labor market training & 1.3 & 1.9 & 5.5 & 13.9 & 12.2 & 6.7 \\
\hline ALM participants. \% of total jobseekers & 26.4 & 30.0 & 32.5 & 40.7 & 38.1 & 38.3 \\
\hline
\end{tabular}


It may be presumed that no matter how common a particular labor market problem is among the general population, it will always tend to hit the immigrant population even harder. At the turn of the century, Finnish citizens faced considerable problems in the labor market. Among working-age Finns, a total of 10 percent were either unemployed or undergoing ALM measures. In addition, 11 percent of the working-age population was receiving a pension (Statistical Yearbook of Pensioners in Finland 2001). Among immigrant groups, the largest share of those either unemployed or undergoing active measures was seen among refugees ( 43 percent) and those from Russia or the former Soviet Union (39 percent). The corresponding shares for Estonians and Westerners were 22 percent and 10 percent (i.e. the same as for Finns), respectively.

Table 3 shows that a little more than one in five Finnish citizens seeking employment on the open labor market were undergoing active measures. Finnish participants in ALM measures were fairly equally divided between those in supported employment and those in labor market training (including workplace training).

We may assume that the greater the cultural divergence between the Finnish society and the immigrant's country of origin, the larger the need for ALM measures. For immigrants, active measures are more than a way to gain necessary vocational qualifications; rather, they often play an essential role in teaching the immigrants about Finnish society (Forsander 2002). Table 3 indicates that the labor market policies implemented at the time of study did not fully comply with this principle. Among refugees, the share of those undergoing active measures was only the second largest of all (35 percent), being exceeded by immigrants from Russia and the former Soviet Union (40 percent). In both groups active measures consisted to a large extent of labor market training. In all ethnic groups, more active measures were targeted to women than to men.

Figure 2 analyzes the labor market orientation of Finns and various immigrant groups, focusing on unemployed jobseekers, participants in ALM measures, and students receiving financial aid. Young people under the age of 25 are examined separately because of their central role in the efforts to break the chain of inherited marginalization. The analysis is limited to those aged 18 or above, as persons under the age of 18 are normally not eligible for student financial aid on account of parental income and residence with their parents. Among those over 18, financial aid recipiency is indicative of the number of full-time students in the age group, though parental income can here, too, disqualify a student for financial aid. For this reason, the share of financial aid recipients significantly underrepresents the actual number of students, especially among Finnish citizens. (Furthermore, conscription reduces the number of Finnish males in this age group entering the labor market). 
Figure 2. share of persons studying, in active labor market measures or unemployed by age, sex and nationality, $\%$.

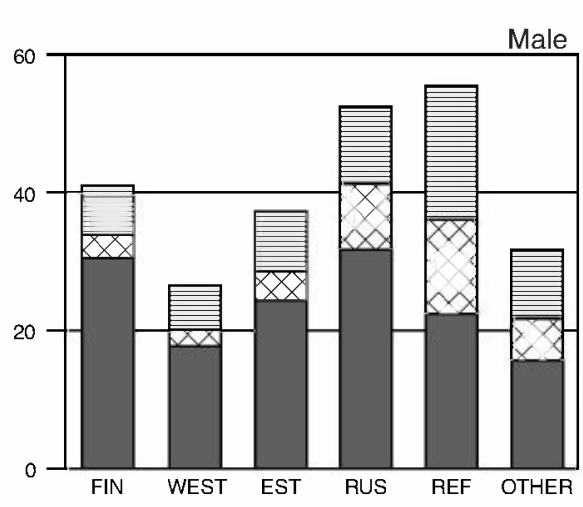

Age 18-24
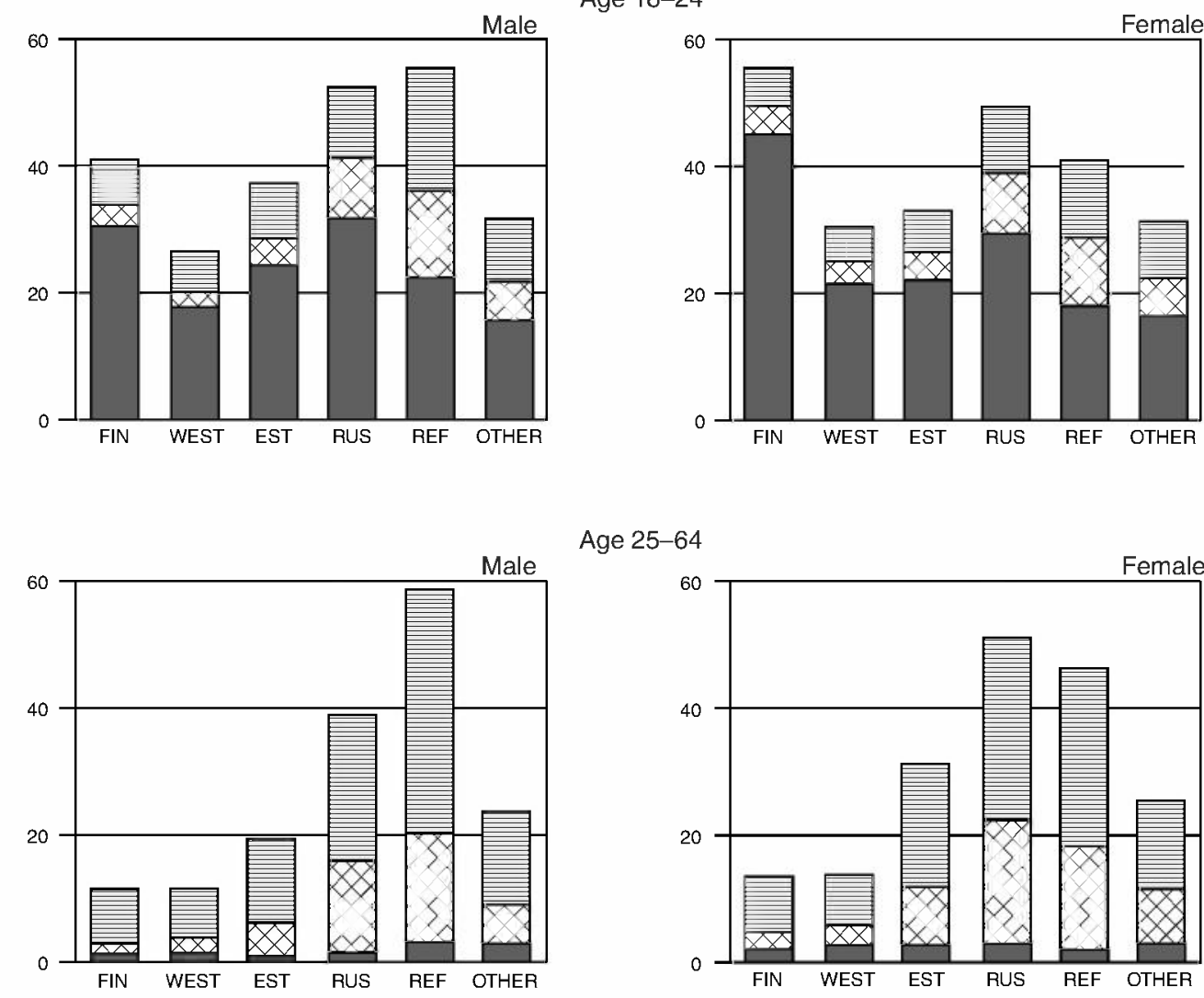

Age 25-64

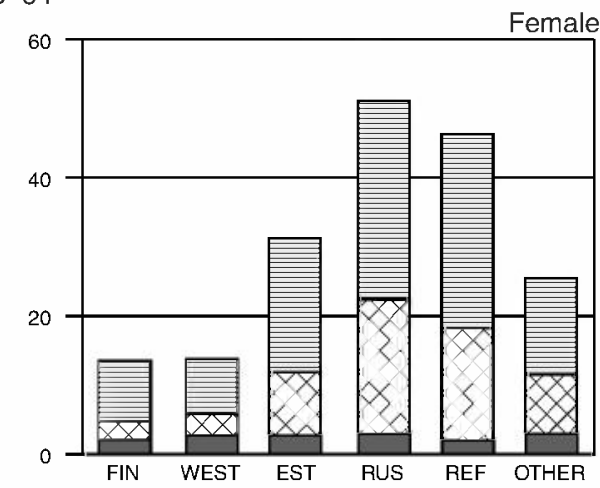

Studying

XX In activation

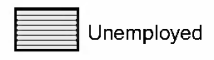

Figure 2 supports the results obtained by Forsander (2002), who found that immigrants from Russia and the former Soviet Union as well as refugees have a high participation rate in training and education, both within the general education system and the ALM arrangements. Among immigrants from Russia and the former Soviet Union of both sexes and between ages 18 and 24, around 40 percent either study or are undergoing ALM measures. Among male refugees, the participation rate was only five percentage points lower, and among female refugees, ten percentage points lower than among male Russian immigrants. In the population over 25, about one in five refugees and Russian/Soviet immigrants were studying or undergoing ALM measures. 


\section{Concluding remarks}

The aim of this study was to provide basic data about benefit recipiency in various key immigrant groups. In a Nordic comparison, Finland is distinctive both for its relatively small number of refugees and the large number of Russian and Estonian immigrants. Another feature specific to Finland is the large group of 20,000 Ingrian Finns who have entered in Finland on ethnic grounds. As the study was only concerned with cash income transfers, the results do not admit more general conclusions about larger trends and directions in social policy as it applies to various immigrant groups.

The results support the assumption that the affluent Finnish welfare state will be able to withstand the pressures facing the social security system. Immigrants currently number only around 150,000, many of whom have already obtained Finnish citizenship. Greater tolerance towards immigrants has been achieved partly through deliberate policy decisions, one aspect of which is the summary examination of asylum applications considered to be without merit. There seem to be no indications in Finland of populist movements such as those in Denmark or the Netherlands.

A central finding of this study is that a substantial share of the immigrants who entered Finland in the 1990s are being integrated into the work-oriented Finnish society by means of social security and active labor market policies. Refugees, having found it particularly difficult to find employment, have the highest recipiency rates for various benefits compared to Westerners, Russians and Estonians. The study reinforces the notion that integration into the labor market is in Finland held to be a basic right almost akin to citizenship. However, immigrants are not the only group at risk of marginalization: another group in danger of being left behind by mainstream society are the long-term unemployed. In this broader context, the labor market situation of immigrants is best seen as part of a larger problem of structural unemployment. As this problem is addressed, therefore, immigrants must be considered as one of several groups deserving special attention.

\section{References}

Djuve, Anne Britt, Hanne Cecilie Kavli, Monica Lund, and Tina Østberg. 2001. Fra sosialhjelp til lonnet kvalifisering. Resultater fra forsek med heldags introduksjonsprogam for flyktninger [From welfare benefits to salaried work. Results from the program to employ refugees.] Fafo-rapport 364. Forskningsstiftelsen Fafo.

Finland's national action plan for employment. April 2001. In accordance with the EU's Employment Guidelines. Available from: $\leq$ http://www.mv.helsinki.fi/jafs/links.html $>$

Forsander, Annika. 2002. Luottamuksen ehdot. Maahanmunttajat 1990-luvun suomalaisilla työmarkkinoilla. [Conditions of trust. Immigrants in the 1990's Finnish labor market.] Väestöntutkimuslaitoksen julkaisusarja D 39/2002. Helsinki: Väestöliitto. 
Jaakkola, Magdalena. 1999. Maahanmuutto ja etniset asenteet. Suomalaisten suhtautuminen maahanmuuttajiin 1987-1999. [Immigration and ethnic attitudes. The attitudes of Finns towards immigrants in 1987-1999.] Työpoliittinen tutkimus 213. Helsinki: Työministeriö.

Laukkanen, Erkki. 2001. EU:n laajeneminen ja maahanmuutto. [E.U. enlargement and immigration, with English summary]. Työpolitttinen aikakauskirja [Finnish Labor Review] 44(1):62-73.

Paananen, Seppo. 2002. Maahanmuuttajien hyvinvointi. [The well-being of immigrants] In: Kotomaana Suomi. Kertomuksia maahanmuutosta 1999-2001 [Finland, my land. Stories about immigration 1999-2001], edited by Outi Lepola, pp. 184-189. Helsinki: Työministeriö $\&$ Edita.

Pinomaa, Simo. 2001. Riittääkö työvoima Suomessa? [Will there be enough labor in Finland?] Työpoliittinen aikakauskirja [Finnish Labor Review] 44(1):56-61.

Sander, Ake. 1997. Some reflections on the integration of ethnic minorities in a modern welfare state. Bosnier i Göteborg - en studie om integration och mångkulturalitet. Projektrapport I. Göteborg: Göteborgs universitet.

Sosiaalimenojen kehitys pitkällä aikavälillä. 2002. [The long-term development of social protection expenditure]. SOMERA-toimikunnan taustaraportti. Julkaisuja 2002:21. Helsinki: Sosiaali- ja terveysministeriö.

Statistical Yearbook of Pensioners in Finland 2001. Helsinki: Central Pension Security Institute and the Social Insurance Institution of Finland 2002.

Statistics Finland. 2002. Foreigners and international migration 2001. Population 2002: 8. Helsinki: Statistics Finland.

Vesterinen, Pentti. 2002. Maahanmuutto - ikääntymisongelmiemme ratkaisu? [Immigration a possible solution to the problems posed by an aging population] Keskustelualoitteita 69. Valtiovarainministeriö. Kansantalousosasto.

VNK. 2001. EU:n laajentuminen ja Suomi. [E.U. enlargement and Finland] Valtioneuvoston kanslian julkaisusarja 2001/1. Valtioneuvoston kanslia, talousneuvoston sihteeristö.

VNS 5/2002. Valtioneuvoston selonteko kotouttamislain toimeenpanosta. [Government report on the implementation of the Act on Integration Assistance for Immigrants] Työministeriö. Available from: $\leq$ http://www.mol.fi/migration/selonteko.pdf $>$

Wadensjö, Eskil. 1999. Economic Effects of Immigration. In: Immigration to Denmark. International and national perspectives, edited by David Coleman and Eskil Wadensjö, pp. 290-328. The Rockwool Foundation Research Unit. Aarhus University Press. 